\title{
The Impact of Organization culture and Work Environment on Employee Engagement and It's Implication on Employee Performance of The Automotive Industry In Jakarta, Indonesia.
}

\author{
Dr. Machmed Tun Ganyang, S. E., M. M. \\ Kalbis Institute, Jalan Pulomas Selatan kav. 22, Pulomas, \\ Jakarta 13210, Indonesia.
}

\begin{abstract}
This study aims to determine and analyze the impact of organization culture, work environment on employee engagementt and it's implications on employee performance. This research uses quantititaive approarch. Population of this research is the whole employee of the automotive industry and sample is 86 respondents. The result of this hypothesis test show that (1) Organization culture has a direct, positive, and statistically significant impact on employe engagement; (2)Work environment has a direct, positive and statistically significant on employee engagement; (3) Employee engagement has a direct positive and statistically significant on employee performance.
\end{abstract}

Keywords: Organization culture, work environment, employee engagement. employee performance, automotive industry.

\section{INTRODUCTION}

Any organization have their own organization culture. Organization culture is one of such factor can affect the employee engagement. Organization culture also can affect the employee performance within the company. The company as an organization rely on it's human resources for achieving the company goals. Therefore, role of organization culture on human resources is very important. Schein (1992) devide organization culture into three level, such as (1) Behavior and artifact; (2) Value; (3) Belief. As an automotive manufacturing has organization culture called ICARE, that consits of (1) Integrity; (2) Commitment; (3) Accountability; (3) Respect; (4) Excellent Innovation. In order to implement the organization culture, new employee was introduced to ICARE which is in line with their work activities. Nevertheless the result of the implementation of the organization culture was less in achievement that affect the employee engagement and employee performance. Likewise the implementation of work environment either in term of soft environment, in term of hard environment, still less in achievement, which is affect the employee engagement and employee performance. Some sense of organization culture, as proposed by Nazir and Zamir (2015), organizational culture is the combination of expectations of organization, experiences, philosophy and values. Organizational culture is also called corporate culture. Organizational culture influences performance and productivity of organization. It gives guidelines for quality of product, punctuality, safety and other factor affecting on environment. organizational culture view as a combination of ecpectation, experiences, philosophy and value. Cameron and Quinn, (2006) in Mohanty, J, and Rath, B, P, (2012) found that it is difficult to find a highly successful company that does not have a distinctive, readily identifiable organizational culture because of its powerful effect on performance and long-term effectiveness. The pressure is the powerfull effect of organization culture on employee performance. Meanwhile, organizational culture as described by Robbins \& Coulter in Tsai, Y, (2010) as the shared values, beliefs, or perceptions held by employees within an organization or organizational unit. This sense view the organizationa culture that focused on share activity within organization related to values, 
beliefs, and perceptions. Relevant to the prior definition, Salam, A., Q, A, (2002) in Zeyada (2018), said the organizational culture reflects the values that are shared by individuals in an organization, and these values, in turn, will affect the humanitarian aspects of the organization and in the concrete behavior of individuals. This opinion implies the values was shared affect the humatarian aspect of the organization and in concrete behavior of individual. Meanwhile Azizollah, et al (2015), said the idea to consider organizations as culture is a system of values shared among the members which is a relatively new phenomenon. This opinion view organozational culture as a system of value shared. While the meaning of the organization culture according to Robbins (2002) in Darsana (2013), organization culture is a system of value share held by members of the organization, which distinguishes of one organization from other organizations. Then, some opinion regarddsing work environment as proposed by Sedarmayanti (2011) said that work environment as the whole tools and materials that is used in the job, include environment around work place, work methode, work arrangements, either as individual or as group. This opinion view work environment as soft environment and hard environment. Work environment as a place where the employees do their job every day. The conducive work environment enable employees do their best. Work environment can impact on employee emotional. Work environment also covered the relationship of staffs and manager or director and physical work environment (Ratana, 2014). This opinion view work environment in a wider meaning. Meanwhile (Sedarmayanti, 2009) in Sanny and Kristanti (2012) said that non physical environment is all the condition occured related to the work relationship of the head and the worker. Work environment will push employee motivation and lead to the improvement of employee creativity. As said by Sedarmayanti (2011) that there are some factors that impact work environment related to employees performance such as : (1) Lighting and light; (2) Temperature; (3) Humidity; (4) Air Circulation; (5) Noise; (6) Smell; (7) Layout color; (8) Decoration; (9) Music; (10) Safety. Those are the factors that impact on hard work environment. Meanwhile the factors impact on soft work environment proposed by Umar (2018), such as : (1) Excellent communication between the head and the staffs and fellow coworkrers; (2) Excelent relationship of fellow coworkers; (3) Excellent work arrangement and ability to adapt with the environment. Next, some definitions regarding employee engagement, such as proposed by Kazimoto, P, (2016) said, employee engagement has been perceived as a motivational factor for organization's objectives achievement. The good environment offered to the worker enables him do the best for the organization goals and objectives achievement. This opinion consider employee engagement as a motivational factor which was offered to employee in order to achieve the goal and objective of the organization. While Vaidyanathan, G, Maheswari, T, U, (2016), said that the concept of employee engagement is most widely used in all progressive organizations, it is about how happy employees are with their jobs, or the environment in which they work with their colleagues and how their performance is aligned with the organizational outcomes. This opinion view employee engagement as the happiness of the employees in their jobs and with this condition, their performance will be aligned with organization performance. Meanwhile Lumina (2014) in Kazimoto (2016) argued that employees were engaging in a complex transactions that were structured in such manner in order to improve the financial performance of the organization. There are many aspects of life and not only services that characterised by strong employee engagement. This argumentation has more wide understanding of employee engagement. Employee engagement is known has a positive effect on organisational and individual productivity and performance (Amah \& Sese, 2018). This opinion consider the positive effect of employee engagement on organizational and individul performance. Paile, P, et al (2013), said that environmental performance reflects an output demonstrating the degree of firms are committed to protecting the natural environment. The opinion of Dinka, D, D, (2018), said that employee performance or job performance is aggregated value to an organization, the set of behaviors that an employee contributes both directly and indirectly to organization goals. This 
opinion consider employee performance as a set of constributions of the employees to the organization goals. Furthermore, sense of employee performance as proposed by Nazir, and Zamir (2015) An employee performance based upon the combination of good working skill and work environment. There is need of some sort of motivation to get the good performance of the employees. As the theory of motivation, it can come from remuneration and other incentives.

The work of employee is made up by employee achievement of the organization's mission, that shows the limits of performance (Cascio, 2006). The achievement of objectives of organization has been designed based on employee performance (Richardo, 2001). An employee's achievement when he gains the goals of organization at workplace is called performance (Cascio, 2006).Different researches have identifies different thoughts, attitudes and beliefs of performance as it helps in measurement of input and output effectiveness measures that guide transactional relationship ( Stannack, 1996).

\section{Statement of a Problem}

Problem formulation of this research are : (1) How is the impact of organization culture on employee engagement; (2) How is the impact of work environment on employee engagement; (3) How is the impact employee engagement on employee performance.

\section{Research Purpose}

\section{The research purpose are :}

(1) To analize the impact of organization culture on employee engagement; (2) To analyze the impact of work environment on employee engagement; (3) To analyze the impact of employee engagement on employee performance.

\section{Desain and research Framework}

\section{RESEARCH METHOD}

The researcher uses descripteve and quantitative method, by describing the status of the object of the research when it's conducted. This study aime to exemine the relationship of three independent variables, such as; (1) organization culture;(2) work environment; (3) employee engagement on one dependent variable (employee performance). Previous research indicates that : (1) There is statisticall significant impact of organization culture on employee engagement; (2) There is stattistical significant impact of work environment on employee engagement; (3) There is statistically significant impact on employee citizensih on employee performance, which is performance can be measured by the achievement of the employee. The reseach framework clearly difined on figure 1 below :

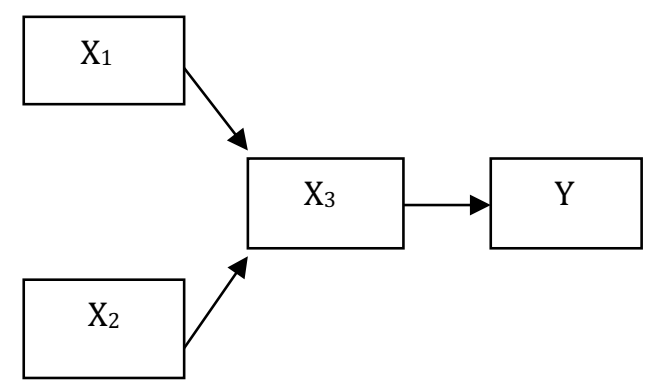

Figure 1. Research Framework

\section{Population and Sample}

The population of the research is employee of the automotive industry, Jakarta and the sample of the research is the employee of, Jakarta amonted 86 (eighty six) employees. 


\section{Hypothesis}

This research used hypothesis, such as : (1) Supected there is positive and statistically significant impact of woek culture on employee engagement; (2) Suspected there is a positive and statistically significant impact of work environment on employee engagement; (3) There is positive and statistically significant impact of employee engagement on employee performance. The research hypothesis above reflected by statistical hypothesis as follows : (1) Ho : there is no positive and statistically significant impact of organization culture on emloyee engagement, $\mathrm{H} 1$ : there is a positive and statistically significant impact of organization culture on employee engagement; (2) Ho : there is no positive and statistically significant impact on employee engagement; (2) Ho : There is no positive and statistically significant impact of work environment on employee engagement, $\mathrm{H} 1$ : there is a positive and statistically significant impact of work environment on employee engagement; (3) Ho : there is no positive and statistically significant impact of employee engagement on employee performance, $\mathrm{H} 1$ : there is a positive and statistically significant impact on employee performance.

In this research author use multiple regression analysis to determine the impact of more than one independent variable on the dependent variable. Processing data using Statistical Package for Social Sciences (SPSS 2.4).

\section{Place and Time of Research Conducted}

The research conducted at the automotive industry, Jakarta from Januay up to September of 2017.

\section{DISCUSSION}

Respondent characteristic as mentioned on Table 1. The Characteristic of Respondents, as follows :

Table 1. Respondent Characteristic

\begin{tabular}{|l|c|c|}
\hline \multicolumn{1}{|c|}{ Gender } & Respondent Amount & Persentage (\%) \\
\hline Men & 63 & 77 \\
\hline Women & 23 & 27 \\
\hline Age & 13 & 15 \\
\hline 17-23 years old & 49 & 57 \\
\hline 24-30 years old & 21 & 24 \\
\hline 31-40 years old & 3 & 3 \\
\hline$>40$ years old & & \\
\hline $\begin{array}{l}\text { Education } \\
\text { Background }\end{array}$ & 0 & 0 \\
\hline Secondary school & 4 & 5 \\
\hline Senior High Scholl & 81 & 94 \\
\hline $\begin{array}{l}\text { Diploma/Bachelor } \\
\text { Degree }\end{array}$ & 1 & 1 \\
\hline Master Degree & & 36 \\
\hline Marrital Status & 31 & 64 \\
\hline Single & 55 & \\
\hline Married & & 36 \\
\hline $\begin{array}{l}\text { Working } \\
\text { Experience }\end{array}$ & 15 & 22 \\
\hline 1-2 years & 31 & 24 \\
\hline 3-5 years & 19 & \\
\hline 5-10 years & 21 & \\
\hline$>10$ years & & \\
\hline
\end{tabular}

Based on gender, founded that men is 63 employees equal to $77 \%$ while women 33 employees, equal to $23 \%$. In term of age, was dominated by the age between 24-30 years old, amounted 
49employees, equal to 57 percent. In the view point of education background was dominated by diploma/bachelor degree, is 81 employees, equal to 94 percent. Based on marrital status, dominated by married status, amounted 55 employees, equal to 64 percent, followed by single status amounted 36 employee, equal to 36 percent.

By the view point of working experience dominated by the employee who have being worked for the company between 3 to 5 years, amounted 36 percent.

\section{Discussion}

Generally simple regression equation can be repesented by $\mathrm{Y}=\mathrm{a}+\mathrm{bx}_{1}+\mathrm{bx}_{2}+\ldots$ After calculate using SPSS 2.4, it is found the coefficient of regression of sub model 1, as stated on table 2 Coefficient below.

Table 2. Regression Coefficient of sub model 1 Unstandarized Coefficient Standarized

\begin{tabular}{|c|c|c|c|c|c|c|}
\hline \multicolumn{7}{|c|}{ Coefficient } \\
\hline Model & & B & $\begin{array}{l}\text { Standart } \\
\text { Error }\end{array}$ & Beta & $\mathrm{t}$ & Sig \\
\hline \multirow[t]{3}{*}{1} & Constant & 19.726 & 6.128 & & 3.219 & .321 \\
\hline & $\begin{array}{l}\text { Organization } \\
\text { culture }\end{array}$ & 0.119 & 0.119 & 0.105 & 0.999 & .002 \\
\hline & $\begin{array}{l}\text { Work } \\
\text { Environment }\end{array}$ & 0.330 & 0.083 & 0.419 & 3.991 & .000 \\
\hline
\end{tabular}

a.Dependent Variable Employee Engagement

From the table above, the regression equation will be $\mathrm{Y}=19.726+0.119 \mathrm{X}_{1}+0.330 \mathrm{X}_{2}$. The constant figure of unstandarized coefficient is 19.726, it means if organization culture and work environment value is 0 , the employee engagement value is 19.726 . Then the organization culture coefficient 0.119 , means organization if the other independent variable is constant, if organization culture increase one level so employee engagement coefficient will increase as 0.119 . The work environment coefficient as 0.330 , it is mean if other independent variable is constant, so if work environment increase one level so employee will increase as 0.330 . It can be concluded that work environment impact on employee engagement statsically significant.

Calculation of regression coefficient of sub model 2, generate the regression coefficient, as stated on table 3 .

Table 3. Regression Coefficient of Sub Model 2

Unstandarized Coefficient Standarized

Coefficient

\begin{tabular}{|l|l|c|c|c|c|c|}
\hline Model & & B & $\begin{array}{c}\text { Standart } \\
\text { Error }\end{array}$ & Beta & t & Sig \\
\hline 1 & Constant & 25.081 & 4,987 & & 5.030 & .000 \\
\cline { 2 - 7 } & $\begin{array}{l}\text { Organization } \\
\text { culture }\end{array}$ & -0.071 & 0.092 &.-0.077 & -0.769 & 0.444 \\
\cline { 2 - 7 } & $\begin{array}{l}\text { Work } \\
\text { Environment }\end{array}$ & 0.101 & 0.069 & 0.158 & 1.433 & 0.150 \\
\cline { 2 - 7 } & $\begin{array}{l}\text { Employee } \\
\text { Engagement }\end{array}$ & 0.325 & 0.84 & 0.403 & 3.857 & 0.000 \\
\hline
\end{tabular}

Dependent Variable : Employee Performance

The result of calculation of coefficient regression of sub structure 2 , found the value of constant 25.081, means if organization culture, work environment, and employee engagement value is 0 , so employee performance will be 25.081. Then regeression coefficient of organization 
culture is -0.071 , indicates there no statiscally significant impact of organization culture on employee performance, simultantly. Then regression coefficient of work environment is 0.101 , it's mean that there is no statistically significant impat of work environment on employee performance, simultantly. The regression of employee engagement is 0.325 , indicates that there is statistically significant impact of employee engagement on employee performance. It means, if the other independent variable constant, the if employee engagement increase one level so, employee performance will incease 0.325 . According to the calculation result of multiple regression coefficient, can be conclude that employe engagement has an impact a statistically significant impact on employee performance. It is also found that the biggest value of $t_{\text {count }}$ is $t_{\text {count }}$ of employee engagement 3.857. The calculation of adjusted $R$ square generate figure of 2.50. This figure has a meaning that the impact of organization culture and work environment on employee engagement and their implication on employee performance is 25 percent. The rest 75 percent was impacted by the others.

\section{CONCLUSION}

Based on the hypothesis testing by compare $t_{\text {count }}$ and $t$ tabel, if $t_{\text {count }}>t$ tabel it can be conluded that there is a significant impact. Based on the calculation it's found that (1) organization culture's $t$ count is -0.769 less than $t$ table 1.989 , it's can be concluded that there is no statistically significant impact of organization culture on employee engagement; (2) work environment's t count is 1.433 less than $t$ tabel 1.989 , thus it's can be conclude that there is no statistically statistically significant impact of work environment on employee engagement; (3) employee engagement's $t$ count is 3.857 greater than $t$ tabel amounted 1.989. so it's can be concluded there is a statistically significant impact of employee engagement on employee performance.

Since there is a a finding that employee engagement has a statiscally significant impact of employee performance, so if the company want to inrease employee performance it can be done improve employee engagement. This finding in line with previous theoritical studyand previous research.

\section{Reference}

Amah, 0, E, (2018), Employee engagement in Nigeria: The role of leaders and boundary variables, African Online Scientific Information Systems; Vol. 44 (2018).

Azizollah, et al 0,The Relationship Between Organizational Culture and Organizational Commitment in Zahedan University of Medical Sciences. Globsl Journal Health anf Science, Published online 2015 Dec 15. doi: $10.5539 /$ gjhs.v8n7p195.

Darsana, M, (2013), The Influence Of Personality And Organizational Culture On Employee Performance Through Organizational Citizenship Behavior, The International Journal Of Management,; Vol. 2, issue 4, page 36.

Dinka, D, D, (2018), Organizational Citizenship Behaviour and Employees' Performance Assessment: The Case of Dire Dawa University. American Journal of Theoretical and Applied Business; Volume 4, Issue 1, March 2018, Pages: 15-26.

Kazimoto, P, (2016), Employee Engagement and Organizational Performance of Retails Enterprises, Scientific Research; Vol. 6, No 4.

Mohanty, J, Rath, B, P, (2012), Influence Of Organizational Culture On Organizational Citizenship Behavior: A, Three-Sector Studyglobal Journal Of Business Research; Vol. 6, No. 1.

Nazir, N, Zamir, S, (2015) Impact of Organizational Culture on Employee's Performance, Industrial Engineering Letters www.iiste.org, ISSN 2224-6096 (Paper) ISSN 2225-0581 (online), Vol.5, No.9, 2015.

Paile, P, et al (2013), The Impact of Human Resource Management on Environmental Performance: An EmployeeLevel Study. Springer Science+Business Media Dordrecht 2013.

Ratana, A.S. (2014). Pengaruh Alur Kerja Dan Lingkungan Kerja Pada PT. Minamas Gemilang Kantor Pusat Jakarta Dampaknya Terhadap Kepuasan Kerja Karyawan. Tesis Magister Ilmu Manajemen Pada Universitas 
Katolik Indonesia Atma Jaya. Jakarta (Free translation : The Impact of Work flow and Work Environment at PT. Minamas Gemilang Head Office on Employee Job Satisfaction, Thesis Magister Management of Atmajaya Catholic University, Jakarta)

Sanny, L., \& Kristanti, S. (2012). Pengaruh Lingkungan Kerja dan Job Insecurity Terhadap Motivasi Kerja dan Dampaknya Pada Kinerja Karyawan Outsourcing Mall Lippo Cikarang (Free Translation, The Effect of Work Environment and Job Insecurity on Outsourcing Employee Performance of Lippo Cikarang Mall). Binus Business Review, Vol. 3, 61-69.

Sedarmayanti. (2011). Tata Kerja dan Produktivitas Kerja Cetakan Ke-3. Bandung: Mandar Maju.

Tsai, Y, (2010), Relationship between Organizational Culture, Leadership Behavior and Job Satisfaction, BMC Health Services Researchhttps://doi.org/10.1186/1472-6963-11-98

Umar, H. (2008). Metode Penelitian Untuk Skripsi dan Tesis Bisnis. Jakarta: Rajagrafindo Persada (Free translation Research Method of Business Minithesis and Thesis. Jakarta)

Zeyada, M, (2018), Organizational Culture and it's Impact on Organizational Citizenship Behavior, International Journal of Academic Research of Business and Social Science, https://.dx.doi.org/10.6007/IJARBSS/v8-13/3939.

Vaidyanathan, G, Maheswari, T, U, (2016) Employee Engagement: A Literature Review, International Journal of Human Resource Management and Research (IJHRMR) ISSN(P): 2249-6874; ISSN(E): 2249-7986 Vol. 6, Issue 2, page 21-3 